Wiesław Theiss

Uniwersytet Warszawski

\title{
WYCHOWANIE I NIEPODLEGEOŚĆ. IDEA POLSKIEJ SZKOŁY W PUBLICYSTYCE SPOEECZNO-OŚWIATOWEJ HELENY RADLIŃSKIEJ (1907-1918)
}

[Education and independence. Helena Radlińska's idea of a Polish school in socioeducational journalism (1907-1918)]

Summary: Helena Radlińska (1879-1954) was both a historian and an educator. In the years 1907-1918 she was a known activist of the independence camp, a movement which was led by Józef Piłsudski and that fought for independence of the country. Within the historical climate of the times, including political disputes and conflicting visions for an independent country, Radlińska created and promoted the concept of a Polish school. This project was bold, uncompromising and forward-looking. It referred to the tradition of the National Education Commission and the experience of the democratic schools, among others, in the United States and Switzerland. Above all, however, it took into account the educational needs of Polish society, the period of the Partitions, and the future independence of the country. The project evolved from a school fighting with the educational structure put forth by the occupying powers and with the educational programs of conciliatory national environments, through a "social school" which, following the model of the "school of free Poland", was supposed to ensure education for all children, regardless of social, economic, or religious differences, to a school centered on the education of patriots and engaged citizens and on implementing a program of indepth knowledge about Poland. The groundbreaking and forward-looking project of the Polish school, which was built by Radlińska, was based on inalienable democratic values, and as such, occupies an important place in the history of Polish educational and pedagogical thought in the first two decades of the twentieth century.

Keywords: Helena Radlińska, Krakow, independence camp, democratic traditions of education, national action, the struggle for culture, educator-fighter, social school, cultural and social work, social pedagogy 


\section{Wstęp}

Lata 1906-1918 zapisują się w życiu i twórczości Heleny Radlińskiej jako okres wytężonej pracy oświatowej, społecznej i politycznej ${ }^{1}$. Pomimo młodego wieku Radlińska ma już wtedy za sobą intensywną działalność w tajnych i jawnych pracach społeczno-oświatowych Królestwa Polskiego, w tym m.in. współkierowanie strajkiem szkolnym w 1905 roku, znaczny dorobek popularyzatorski, a także pobyt na Syberii, gdzie towarzyszyła mężowi Zygmuntowi Radlińskiemu skazanemu za udział w pracach politycznych Polskiej Partii Socjalistycznej. Przed sobą zaś, począwszy od 1906 roku, studia historyczne w Uniwersytecie Jagiellońskim, bardzo wytężoną aktywność w Uniwersytecie Ludowym im. Adama Mickiewicza, przygotowanie wielkiej publikacji zbiorowej Praca oświatowa (1913) ${ }^{2}$, współpracę ze związkowymi organizacjami nauczycielskimi, a przede wszystkim żywy udział w różnych strukturach społeczno-wojskowych obozu niepodległościowego Józefa Piłsudskiego. Pracuje wówczas zarówno w kręgu polityków i wojskowych (to m.in. Kazimierz Bagiński, Stanisław Kot, Juliusz Poniatowski, Władysław Sikorski, Kazimierz Sosnkowski, Leon Wasilewski), jak i oświatowców oraz pedagogów (m.in. Władysława Dawida, Konstantego Krzeczkowskiego, Faustyny Morzyckiej, Henryka Rowida, Władysławy WeychertSzymanowskiej). Warto dodać, iż okres spędzony w Krakowie Radlińska wspomina jako „najpiękniejszy (...), najbardziej twórczy i płodny dla prac następnych. $\mathrm{Z}$ wielu też względów za - najszczęśliwszy (pomimo przebycia

\footnotetext{
${ }^{1}$ Helena Radlińska (2.05.1879-10.10.1954) - twórczyni polskiej pedagogiki społecznej. W 1925 r. zorganizowała Studium Pracy Społeczno-Oświatowej Wolnej Wszechnicy Polskiej w Warszawie. Do 1939 r. była aktywną działaczką wielu polskich oraz europejskich stowarzyszeń i organizacji oświatowo-pedagogicznych. W latach 1945-1950 pracowała jako profesor Uniwersytetu Łódzkiego. Opublikowała kilkaset prac z zakresu pedagogiki społecznej, historii wychowania, oświaty dorosłych, bibliotekarstwa oraz pracy społecznej, w tym m.in.: Kto to byt Mickiewicz (1897), (współred.) Praca oświatowa (1913), Ksiażka wśród ludzi (1929, wyd. IV, 1946), Stosunek wychowawcy do środowiska spotecznego (1935), (red.) Społeczne przyczyny powodzeń i niepowodzeń szkolnych (1937), Oświata dorostych (1947), Pisma pedagogiczne (1961-1964). Zob. m.in.: I. Lepalczyk, W. Skibińska, Helena Radlińska. Kalendarium życia i pracy. „Roczniki Biblioteczne” 1974, z. 1-2; A. Jaworska, Działalność Heleny Radlińskiej w Uniwersytecie Ludowym im. Adama Mickiewicza $w$ Krakowie $w$ latach 1906-1918. „Roczniki Biblioteczne” 1974, z. 1-2; A. Kamiński, Pedagogika spoleczna Heleny Radlińskiej w okresie krakowskim (1908-1914), „Zeszyty Naukowe Uniwersytetu Łódzkiego. Nauki Humanistyczno-Społeczne” 1965, Seria I, t. 40; przedr. w: tegoż, Studia i szkice pedagogiczne, Warszawa 1978, s. 31-57; W. Theiss, Radlińska, wyd. II, Warszawa 1997; tegoż, Radlinska Helena, w: T. Pilch (red.), Encyklopedia pedagogiczna XXI wieku, t. V, Warszawa 2006, s. 29-35; R. Wroczyński, Myśl pedagogiczna i programy oświatowe w Królestwie Polskim na przetomie XIX i XX w., wyd. II, Warszawa 1963; B. Cywiński, Rodowody niepokornych, Warszawa 1996; St. Świdwiński (red.), Pokłosie pracy oświatowej w latach 1880-1928 (Garść wspomnień), Warszawa 1928.

${ }^{2}$ Praca oświatowa, jej zadania, metody, organizacja. Podręcznik opracowany staraniem Uniwersytetu Ludowego im. A. Mickiewicza w Krakowie, Kraków 1913.
} 
beznadziejnej, zdawało się, choroby i dwóch ciężkich operacji w latach 1910 i 1911)"3.

Kraków tamtych lat jest „polskim Piemontem”, ogniskiem walk o niepodległy kraj. Na zewnątrz to miasto spokojne i bezpieczne, ostoja konserwatyzmu i klerykalizmu, z drugiej strony - środowisko żywego życia społecznego, politycznego i artystycznego. Do Krakowa, korzystającego ze względnej swobody politycznej, napływają ludzie zza zaborczych kordonów. Są wśród nich emigranci polityczni, uczeni, artyści, studenci; tu też przez dziesięć lat kierują się tajne uczniowskie wycieczki filomatów z Pomorza (1905-1914). Królewskie miasto jest areną obchodów patriotycznych rocznic, takich jak 50o-lecie bitwy pod Grunwaldem czy wielkiego zlotu wszechsłowiańskiego sokolstwa w 1912 roku, a także mniej lub bardziej gwałtownych manifestacji studenckich. Ale w Krakowie nie brak również, zwłaszcza wśród przybyszów z prowincji, takich zjawisk jak nędza, bezdomność, bezrobocie, włóczęgostwo, alkoholizm. Zmarginalizowanym ludziom z pomocą idą liczne $\mathrm{w}$ mieście instytucje opieki i wsparcia ${ }^{4}$.

Jednym z głównych obszarów i celów pracy społeczno-oświatowej H. Radlińskiej w „krakowskim okresie” jest działalność publicystyczna. Radlińska pisze bardzo dużo i na różne tematy. Publikuje przede wszystkim w „Krytyce” i „Muzeum” (1907-1910), a także w „Wiadomościach Polskich” (1915-1916) oraz w „Kulturze Polski” (1917-1918). Ostatni z tych periodyków, kierowany przez Radlińską, pełni ważną rolę społeczno-polityczną na zapleczu obozu niepodległościowego. Wszystkie jej ówczesne teksty są - jak sama przyznaje - agitacją i propagandą idei czynu niepodległościowego. Mają aktywizować Polaków, budzić społeczeństwo z marazmu, kształtować postawy patriotyczne, usuwać lęki i pobudzać do działania.

Na plan pierwszy omawianej publicystyki H. Radlińskiej wysuwa się zagadnienie polskiej szkoły i wychowania narodowego. Zakres tych wypowiedzi jest rozległy - od tradycji szkolnych i aktualnych potrzeb oświatowych, poprzez zadania i możliwości przebudowy istniejącego szkolnictwa, po udział szerokich kręgów społecznych $\mathrm{w}$ tworzeniu niezależnego polskiego szkolnictwa. Autorka posługuje się przy tym zarówno radykalnymi i porywającymi wizjami szkoły - ogniska kultury narodowej - jak i miażdżącą krytyką szkolnictwa prowadzonego przez zaborców; troska $\mathrm{o}$ przyszłość szkoły polskiej idzie tu $\mathrm{w}$ parze $\mathrm{z}$ projektami konkretnych

\footnotetext{
${ }^{3}$ H. Radlińska, Listy o nauczaniu i pracy badawczej, w: tejże, Z dziejów pracy społecznej $i$ oświatowej, wstęp J. Hulewicz, wyb. i opr. W. Wyrobkowa-Pawłowska i J. Wojciechowska, Wrocław-Warszawa-Kraków 1964, s. 359.

${ }^{4}$ Zob. K. Grodziska, J. Purchla, Kraków, w: Z. Najder i in. (red.), Węzhy pamięci niepodległej Polski. Warszawa-Kraków 2014, s. 353-362; Mit Galicji, oprac. zbior., Kraków 2014. W wymienionych opracowaniach została pominięta prowadzona w Krakowie i na innych terenach Galicji działalność niepodległościowa Józefa Piłsudskiego.
} 
rozwiązań organizacyjno-programowych; opisywany obraz człowieka zniewolonego przez zaborców kontrastuje $\mathrm{z}$ sylwetką patrioty zaangażowanego w życie kraju. Wspólnym mianownikiem tych wypowiedzi jest świadomość wielkiej roli, jaką relacja szkoła (wychowanie) - państwo odgrywa $\mathrm{w}$ procesach przekształcania struktury i kultury społeczeństwa, a także - kształtowania obywatela przyszłej niepodległej ojczyzny.

Przedstawione tu poglądy Radlińskiej, oparte na fundamentalnych wartościach demokracji, ewoluują od idei szkoły jednolitej i krytyki obcego szkolnictwa, poprzez koncepcję szkoły uspołecznionej, przedstawianej na tle nowopowstającej pedagogiki społecznej, po elementy projektu państwowej i powszechnej szkoły niepodległej Polski.

\section{Walka o kulturę i jednolita szkoła polska}

Już w 1907 roku H. Radlińska w artykule Walka o kulturę przedstawia zręby swojego stanowiska $\mathrm{w}$ sprawach społeczno-politycznych oraz oświatowoszkolnych. Jest to nieledwie programowe wystąpienie, głos bardzo wyrazisty, radykalny, odwołujący się nawet do socjalistycznych haseł Rewolucji Francuskiej. Autorka w pierwszym rzędzie przywołuje idee sprawiedliwości i demokracji oraz - co warto osobno podkreślić - wolności i praw człowieka, a za główny cel działania społecznego uznaje „czyn”, to jest walkę z władzą narzuconą przez zaborców oraz z tradycyjnymi autorytetami, które dotąd mają monopol w dziedzinie szkolnictwa i kultury ${ }^{5}$.

Problematyka związku praw człowieka $\mathrm{z}$ dążeniem do zbudowania szkoły polskiej pojawia się już w pierwszej polemice Radlińskiej z hasłami różnych organizacji oświatowych. Autorka wskazuje wtedy, iż walka o szkołę dotyczy zgoła czego innego aniżeli domaganie się li tylko szkoły powszechnej, bezpłatnej i obowiązkowej. Że walka ta jest „najściślej z całokształtem życia związana, [to] fragment walki o prawa człowieka, o prawo do wiedzy i do pełni życia" ${ }^{6}$, do wolności osobistej i państwowej. Jest to bardzo ważne i odważne wtedy stwierdzenie. Odcina ono rekonstruowany projekt od innych, podobnie propolskich haseł szkolno-oświatowych, formułowanych jednak na podstawach ugodowych, serwilistycznych czy też wąskonarodowych, nacjonalistycznych. Radlińska wskazuje na konkretne przeszkody, jakie stoją na drodze do wolnej szkoły w wolnym kraju. I mówi wprost: taką główną przeszkodą jest obecne szkolnictwo, które znajduje się w rękach zaborców oraz hierarchii kościelnej; hierarchii - podkreśla Radlińska - nie religii. W obu przypadkach kręgom władzy zależy na „zasłanianiu” obrazu świata, „niedopuszczaniu światła” czy „zaszczepianiu gotowych dogmatów”, gdyż

\footnotetext{
${ }^{5}$ H. Orsza [H. Radlińska], Walka o kulture, ,Wiedza” 1907, t. 2, nr 35 i nr 36.

${ }^{6}$ Tejże, Walka o kulture, ,Wiedza” 1907, t. 2, nr 35.
} 
„wiedza jest uważana za groźną dla władzy garstki nad ogółem, za wyłączny przywilej posiadających”. Stąd fundamentalna i trwale obecna w poglądach Radlińskiej myśl: „Podczas, gdy państwo policyjne i stanowe ogranicza oświatę w interesie władzy, rzeczpospolita demokratyczna uważa, że oświata jest węgielnym kamieniem państwa - ciemnota zaś przeciwnie jest podstawą samowoli" ${ }^{7}$. Z tych też pozycji zwraca uwagę na wątpliwe jej zdaniem - z czym dzisiaj można dyskutować - ideowe podstawy strajku szkolnego dzieci w zaborze pruskim. Uważa, iż ten ofiarny protest dzieci w sprawie nauki religii w języku polskim w istocie nie naruszał funkcjonowania „pruskiej szkoły katowni" 8 .

W artykule Walka o kulturę (1907) H. Radlińska podejmuje jeszcze dwa inne zasadnicze wątki krytyczne: problem minimalizmu potrzeb kulturalno-oświatowych $\mathrm{w}$ społeczeństwie polskim oraz zagadnienie monopolu instytucji oświatowych. Obydwa niebezpieczeństwa są widoczne w bieżącym życiu społecznym Galicji i obydwa w istocie wnikają z lęku przed wpływami socjalistycznymi oraz są wynikiem serwilistycznych postaw wobec zaborcy. Autorka podkreśla, iż w ustroju socjalistycznym nie ucierpią - jak twierdzą antagoniści - ani interesy szkolnictwa niższego, ani szkół wyższych czy muzeów. Jest wręcz przeciwnie - uważa. Pisze na ten temat: „Wszędzie, gdzie klasa robotnicza wywalczyła lepsze warunki bytu, wraz z nimi idzie wspaniały rozwój związków czytelniczych, uniwersytetów ludowych, zawiązywanie kół samokształcenia, stowarzyszeń oświatowych wszelkiego typu”. Dodaje, iż proces ten łączy odrębne dotąd typy: „inteligenta” oraz „robotnika".

Drugi temat - zagadnienie monopolu oświatowo-szkolnego - daje Radlińskiej okazję do ostrej polemiki ze stanowiskiem Narodowej Demokracji oraz pozostającej w jej rękach Macierzy Polskiej i Galicyjskiego Towarzystwa Szkoły Ludowej. Wytacza przeciwko nim zarzut fasadowości, bezideowości oraz bierności. Wymienione organizacje $\mathrm{w}$ dążeniu do utrzymania jak największej liczby zakładów szkolnych podporządkowują się przepisom państwowym, co jest równoznaczne $\mathrm{z}$ "usypianiem społeczeństwa" i „zagłuszaniem własnego sumienia”. Ich działalność nie odpowiada rzeczywistym potrzebom - zarówno w wymiarze ilościowym, jak i ideowym. Postulowane przez Radlińską „nowe” organizacje oświatowe muszą zejść z drogi kompromisów wobec zaborcy, zerwać z dawnymi wzorami i utartymi komunałami, by w to miejsce „budzić głód wiedzy”, budować nową politykę oświatową, ukazywać demokratyczne „stosunki ludzkie”.

\footnotetext{
${ }^{7}$ Tejże, Walka o kulture, ,Wiedza” 1907, t. 2, nr 36.

${ }^{8}$ Tejże, Ze spraw wychowawczych (I), „Krytyka” 1907, z. 1.

${ }^{9}$ Tejże, Walka o kulture, ,Wiedza” 1907, t. 2, nr 36.
} 
Wszystko to jednak jest zaledwie środkiem do celu, gdyż strategiczne zadanie pracy oświatowej sformułowane jest o wiele bardziej radykalnie: „Rozwój kultury wymaga - stanowczo stwierdza Radlińska - głębokiego przewrotu wszystkich stosunków. «Rycerze pracy» i «rycerze ducha» wspólnym trudem wywalczyć muszą lepszą przyszłość"10. Użyte słowo „wywalczyć” wprowadza do pracy oświatowej postać „oświatowca-bojownika”. Jego sylwetkę przybliża następująca uwaga Radlińskiej: „Praca oświatowa nie posunie się wydatnie naprzód, dopóki nie znajdzie zastępów swoich bojowników, swoich fanatyków choćby, szermierzy wyłącznie sobie oddanych" ${ }^{11}$. Postulowane zmiany oświatowe wymagają także zorganizowania nowych instytucji oświatowych, na przykład muzeum oświatowego. Do jego zadań należy, obok gromadzenia materiałów do dziejów oświaty, podejmowanie badań nad potrzebami oświatowymi, politycznymi i społecznymi. Działalność tej placówki będzie daleko wykraczała poza dotychczasowe potoczne rozumienie oświaty, które sprowadza jej sens - jak ironicznie powie Radlińska - „do rozdawania broszurek o «Królowej korony polskiej» czy «Maćku w powstaniu»"12.

Krytykując sytuację szkolno-oświatową w zaborze austriackim, Radlińska zwraca uwagę także na ideał „poczciwego abiturienta”, którego kształtuje szkoła w Galicji. Pisze na ten temat bezpośrednio i rzeczowo: „O kształceniu człowieka zdolnego do samodzielnego określenia swej drogi, wychowania dzielnych duszą i ciałem twórców nowego życia - dzisiejsza szkoła średnia nie myśli wcale. Nauka jest w niej - wyjaśnia dalej przytłoczona przepisami - oderwana od życia, wychowanie zastąpione regulaminem" "13. I dodaje bez ogródek, że podobnie jest w szkole niemieckiej. Ale w krytyce szkoły galicyjskiej Radlińska idzie jeszcze dalej. Z całą mocą podkreśla, że jest to szkoła obca, narzucona, która „hoduje funkcjonariuszy obcej monarchii” i temu celowi podporządkowuje program, plan i zakres nauki, w którym wiedza o historii Polski jest umieszczona wśród przedmiotów nadobowiązkowych ${ }^{14}$. Dlatego konieczna jest m.in. praca uświadamiająca wśród nauczycielstwa, a także walka o polskość literatury dla dzieci i bibliotek z kresów Galicji ${ }^{15}$. Nie dość, że w piśmiennictwie tym razi kicz, że goni ono za sensacją i często jest tylko przeróbką literatury dla dorosłych, to jeszcze

\footnotetext{
${ }^{10}$ Tamże.

${ }^{11}$ H. Orsza [H. Radlińska], Z towarzystw oświatowych (I, II), „Krytyka” 1907, t. 1.

12 Tamże.

${ }^{13}$ H. Orsza, [H. Radlińska], Ze spraw wychowawczych (II), „Krytyka” 1907, z. 2.

${ }^{14}$ Tamże.

${ }^{15}$ H. Orsza [H. Radlińska], Ze spraw wychowawczych, „Krytyka” 1908, t. 1, z. 4; Ze spraw wychowawczych, „Krytyka” 1908, t. 2, z. 8; Ze spraw wychowawczych i towarzystw oświatowych, „Krytyka” 1908, t. 1, z. 1.
} 
ukazuje ono świat społeczny w sposób dalece uproszczony, zhierarchizowany, zamknięty w ramach reguł narzuconych przez zaborców. Aby przeciwstawić się tej tendencji, Radlińska odwołuje się do idei „stulecia dziecka” (bez wymieniania nazwiska Ellen Key), które - jak pisze - „coraz pełniej wschodzi” i które niesie nakaz: „dawajmy dziecku, co mamy najpiękniejszego, dusze rozwinie nie morał, lecz prawda i siła talentu" ${ }^{\prime 6}$.

Program „walki o kulturę”, jaki H. Radlińska kreśli w 1907 roku, a który w istocie będzie jej towarzyszył aż do końca pracy naukowej, zawiera także - a może przede wszystkim? - zarys koncepcji „,szkoły zgodnej z duchem demokratycznym”, rozumianej jako przeciwieństwo „obecnej szkoły formalnej”. Obraz tej szkoły jest bardzo ambitny, rozległy i bogaty - tak od strony ideowej, jak i organizacyjnej. Jest to wzorzec pożądanych i możliwych rozwiązań, które niekiedy wyraźnie opuszczają grunt realiów, by szybować w stronę niedościgłych ideałów społeczno-edukacyjnych.

Na pytanie, jaka to konkretnie ma być szkoła, Radlińska odpowiada następująco:

- jednakowa dla wszystkich, bez ograniczeń społecznych;

- harmonijnie rozwijająca człowieka i wszechstronnie przygotowująca go do życia;

- autonomiczna pod względem programu i planu zajęć; program ma być ułożony przez nauczycieli, a zatwierdzony przez gminę;

- korzystająca z pomocy finansowej i opieki programowej państwa;

- uspołeczniona, to jest otwarta dla wszystkich dzieci, jej kierownictwo spoczywa w rękach nauczycielstwa, a dozór sprawuje wybieralny urząd;

- ściśle współpracująca z pokrewnymi instytucjami nauczania;

- apolityczna, kształcąca ludzi niezależnych, równych obywateli.

Taka szkoła jest szkołą „dla dziecka”. Dzięki niej nie będzie ono już traktowane jako „szczęśliwy poddany”, a środków do nauki nie otrzyma ,jako grosz miłosierdzia, lecz jako należną ze strony społeczeństwa pomoc"17.

Radlińska - uważny i krytyczny obserwator ówczesnych realiów społeczno-oświatowych Galicji - z wyraźną satysfakcją dostrzega pojawianie się pierwszych symptomów zmian na opisywanym polu. Są to hasła reformy szkolnej, obecne w pracach krakowskiego Towarzystwa Nauczycieli Szkół Wyższych oraz postulatach zgłaszanych przez krakowską młodzież. Ci drudzy żądają m.in. rewizji programów nauczania, poszanowania godności ucznia, wolności przekonań, prawa do zakładania organizacji uczniowskich, a także wykładów z higieny oraz wycieczek. Ale Radlińska-bojownik na tym nie

\footnotetext{
${ }^{16}$ Tejże, Sprawy wychowawcze. Literatura dla młodzieży, „Krytyka” 1907, t. 2; tejże, Literatura ludowa, „Krytyka” 1907, t. 1; tejże, Ze spraw oświatowych $i$ wychowawczych. Ksiązki dla młodzieży, „Krytyka” 1910, t. 1; tejże, Ze spraw wychowawczych (II), „Krytyka” 1909, t. 3.

${ }^{17}$ Tejże, Walka o kulture, „Wiedza” 1907, t. 2, nr 36.
} 
poprzestaje. Twierdzi, że „sprawę szkolną” może rozwiązać tylko „czyn”. Wyjaśnia: „Największym błędem jest obawa czynu. Opanować ruch można tylko stając się jego częścią. Szkoła jest własnością ogółu - wyzwolenie jej spod wszelkiej jednostronnej zależności jest najważniejszym dla przyszłości zagadnieniem" $"$.

O tym, jak urzeczywistnić przywołany projekt szkoły demokratycznej, która ma być „miejscem wychowania a nie tresury”, H. Radlińska pisze w ogłoszonej w 1908 roku ważnej rozprawie Nowożytna szkoła elementarna ${ }^{19}$. Zasadniczy punkt ciężkości stanowiska autorki przesuwa się w stronę ekonomiczno-społecznych uwarunkowań funkcjonowania szkoły elementarnej. Niekorzystne warunki bytu, głównie bieda i nędza rodzin oraz spowodowana niedostatkiem praca fizyczna dzieci, tworzą poważne bariery w dostępie do oświaty. Świadczy o tym - jak wskazuje Radlińska - na przykład bardzo niska (najniższa w Galicji) frekwencja szkolna w biednych okręgach szkolnych położonych we Wschodniej Galicji. Zagrożeniem są także szkoły jednoklasowe, które nie są $\mathrm{w}$ stanie zrealizować choćby najlepiej opracowanego programu. Nie wystarczy zatem wprowadzenie obowiązku szkolnego, by zlikwidować analfabetyzm, ale niezbędna jest w tym zakresie pomoc państwa. Takie podstawowe, głównie materialne i organizacyjne, wspieranie szkoły oraz dziecka przez państwo i społeczeństwo Radlińska nazywa uspołecznieniem szkoły. Używa też szerszej interpretacji tego terminu określając je jako „oddanie szkoły obywatelskim jednostkom samorządu”. W obydwu przypadkach idzie o coś więcej aniżeli dostrzeganie niekorzystnych zjawisk społeczno-edukacyjnych i postulowanie zmian. Uspołecznienie jest bowiem wręcz niezbywalną normą i zasadą, którą muszą kierować się w swojej działalności demokratyczna szkoła oraz państwowe władze szkolne.

Czas pokaże, że idea szkoły uspołecznionej, zarówno jej wizja, jak i powstający program, stanie się trwałym i bardzo ważnym elementem poglądów Radlińskiej. Wpłynie na krystalizowanie się już nie tylko koncepcji przyszłej polskiej szkoły, ale obok innych czynników, jak na przykład teorii i praktyki pracy oświatowej oraz pracy socjalnej, złoży się na podstawy głównego dzieła naukowego H. Radlińskiej - pedagogiki społecznej.

\section{Szkoła uspołeczniona i pedagogika społeczna}

25 kwietnia 1908 roku Helena Radlińska podczas posiedzenia Krakowskiego Towarzystwa Nauczycieli Szkół Wyższych występuje z referatem Z zagadnień

\footnotetext{
${ }^{18}$ Tejże, Ze spraw wychowawczych (II), „Krytyka” 1907, z. 2.

${ }^{19}$ Tejże, Nowożytna szkoła elementarna, „Kultura” 1908, z. 7/8.
} 
pedagogiki spolecznej, opublikowanym następnie w periodyku „Muzeum”20. Wraca w nim do ogólnego postulatu „uspołecznienia wychowania i szkoły”. W dalszym ciągu jest to projekt społeczno-polityczny, ale z drugiej strony po raz pierwszy Radlińska tak wyraźnie odsłania jego podstawy naukowe.

Stoją bowiem za tezą o konieczności uspołecznienia szkoły - jak sama podkreśla - studia nad ideałami wychowawczymi nowożytnej doby, zwłaszcza nad programami Komisji Edukacji Narodowej ${ }^{21}$, a także analizy aktualnych systemów szkolnych państw demokratycznych (Anglia, USA, Australia, Szwajcaria, kraje skandynawskie). Są to bardzo ważne argumenty. Radlińska jasno daje do zrozumienia, iż wolna, obywatelska, narodowa szkoła polska nie jest wymysłem bieżącej chwili, wynikiem jakieś gry politycznej, ale przeciwnie, ma swoje korzenie w odległej już polskiej tradycji oświatowej. Jest też zdobyczą demokratycznych społeczeństw Zachodu, gdzie z powodzeniem służy edukacji obywatelskiej. Po trzecie wreszcie, ma ona swoje uzasadnienie w pedagogice społecznej - naukowej i krytycznej refleksji nad społecznymi barierami, które bronią dostępu do kultury i edukacji. W tym ostatnim zakresie Radlińską inspiruje m.in. Ludwik Krzywicki, który jej zdaniem pierwszy na gruncie krajowym wskazał na społeczne tło wychowania, jego zależność od warunków polityczno-społecznych, kładąc tym samym podstawy pod rozwój pedagogiki społecznej ${ }^{22}$.

Jeżeli wymienione racje mają charakter konstruktywny, to druga grupa opinii i ocen formułowanych wtedy przez Radlińską jest zdecydowanie negatywna. Idzie $\mathrm{w}$ tym przypadku (i to już po raz kolejny) o krytykę ówczesnych koncepcji wychowawczych spod znaku Ligi Narodowej. Radlińska kieruje zarzuty wprost do takich zwolenników szkoły i wychowania opartego

${ }^{20}$ H. Radlińska, $Z$ zagadnień pedagogiki społecznej, „Muzeum” 1908, t. 2, cz. II. O tym, że cytowany referat jest rdzeniem stanowiska Radlińskiej i główną osią jej poglądów świadczą jego liczne i różne wersje, prezentowane w latach 1909-1910, a także później. Są to dwie grupy tekstów: I. Streszczenia (Podstawy wychowania narodowego [Tezy referatu i wniosek na Polskim Kongresie Pedagogicznym we Lwowie], „Przewodnik Oświatowy” 1909, z. 11; toż przedr. Podstawy wychowania narodowego, w: J. Kornecki (oprac.), Księga pamiatkowa II Polskiego Kongresu Pedagogicznego, Lwów 1909, s. 65-67; przedr. tegoż w: W. Theiss, Radlińska, dz. cyt., s. 206-209; Podstawy wychowania narodowego (jako fragment artykułu), w: A. Sujkowski, A. Szycówna, Wrażenia z Polskiego Kongresu Pedagogicznego we Lwowie. „Nowe Tory” 1909, z. IX); II. Rozwinięcia ( $W$ sprawie polskiego dorobku wychowawczego, „Muzeum” 1910, t. 1; toż samo: W sprawie polskiego dorobku wychowawczego, „Przewodnik Oświatowy” 1910, z. 1; przedr. tegoż w: H. Radlińska, Z dziejów pracy społecznej $i$ oświatowej, dz. cyt., s. 3-7; Wychowanie narodowe, „Krytyka” 1910, t. 1; przedr. tegoż w: H. Radlińska, Pedagogika społeczna, Wrocław-WarszawaKraków 1961, s. 3-20).

21 Zob. H. Orsza-Radlińska, Kotłątaj jako pedagog. Hugona Kołtątaja nieznane listy o wychowaniu, Lwów 1912; przedr. H. Kottątaja nieznane listy o wychowaniu, „Muzeum” 1912, t. 3; Kottataj jako pedagog, w: Pamięci Hugona Kottataja. Akademia na jego cześć staraniem Tow. Fïlozoficznego w Krakowie 28 II 1912, Kraków 1912.

${ }^{22}$ H. Orsza [H. Radlińska], Ludwik Krzywicki jako pedagog, „Nowe Tory” 1908, z. 8. 
na kulcie przeszłości i tradycji narodowej jak: Stanisław Prus Szczepanowski, Wincenty Lutosławski, Zygmunt Balicki, Julia Benoni-Dobrowolska ${ }^{23}$. Twierdzi, że ich stanowisko ogranicza horyzonty i hamuje dążenia do zmiany, ergo - sprzyja polityce zaborców. Powie nawet, za Stanisławem Wyspiańskim, że taka postawa jest „okradaniem narodowości”. Mocne, bardzo mocne słowa! Nie ma w nich prawie miejsca na argumenty merytoryczne, to raczej pełen pasji atak publicystyczny i polityczny. Po wyraźniejsze argumenty Radlińska sięga wtedy, gdy krytykuje propagowaną przez narodowców „pedagogikę pamięci”. Zauważa także, wykorzystując język polemiki i obrazowe metafory, iż: „W imię szkoły polskiej i odrodzenia narodu wiedzie się młode pokolenie ku mogiłkom i tam lampy zapaliwszy, rozpamiętuje się przeszłość, nie jako tej przeszłości wolni spadkobiercy, lecz dłużnicy niewolni. Sprawie wychowania nie godzi [się] zaś pójść w niewolę jednego hasła, jednej wyłączającej wszystkie inne idei, choćby idei polskiej, z najwznioślejszych chwil przeszłości wysnutej pod odpowiedzialnością przed życiem, któremu ma przygotowywać pracowników"24.

Odsłaniając idee, które przyjmuje i aprobuje, mówiąc też o rozwiązaniach, których nie dopuszcza w swoim projekcie, Radlińska na plan pierwszy wydobywa elementy „obywatelskie i postępowe”, które jednocześnie są „zgodne z nauką i potrzebami życia”, by następnie na tym gruncie rozwinąć ideę szkoły uspołecznionej oraz wychowania społecznego. W tym celu sięga po - jak wyjaśnia - najogólniejszy postulat pedagogiki społecznej: „Dzieci całego narodu są bogactwem jego największym, tworzą przyszłość - w interesie tej przyszłości leży dostarczenie wszystkim możliwości rozwoju" ${ }^{25}$. W wymiarze polityczno-społecznym jest to myśl radykalna. Nie inaczej jest w przypadku wymiaru edukacyjno-wychowawczego. Łączy oba spojrzenia intelektualny i moralny „zamach” na istniejący porządek, tj. niedemokratyczne stosunki społeczne oraz dogmatyczne pojmowanie roli wychowania.

$\mathrm{Na}$ tym tle do głosu dochodzą kategorie „dziecka” oraz „rozwoju”. Dziecko dla Radlińskiej nie jest ani „bosym proletariatem” czy „ludem małorosłym" (Janusz Korczak) skazanym na nędzną egzystencję, ani też

${ }^{23}$ Stanisław Prus Szczepanowski, Wincenty Lutosławski, Zygmunt Balicki, Julia BenoniDobrowolska - przedstawiciele ideologii narodowej, zwolennicy szkoły i wychowania opartego na kulcie przeszłości i tradycji narodowej. Zob. L. Chmaj, Prądy i kierunki w pedagogice XX wieku, Warszawa 1963, s. 287-297; F.W. Araszkiewicz, Ideaty wychowawcze Drugiej Rzeczypospolitej, Warszawa 1978, s. 32-37; R. Wroczyński, Dzieje oświaty polskiej 1795-1945, Warszawa 1980, s. 241-242; S. Wołoszyn, Nauki o wychowaniu w Polsce w XX wieku. Próba syntetycznego zarysu na tle powszechnym, wyd. II, Kielce 1998, s. 154-155; Cz. Majorek, Polska myśl pedagogiczna w zaborze austriackim (1772-1918). „Przegląd Historyczno Oświatowy” 1992, nr 3-4; J. Falkowska, Szkoła ostoja wychowania narodowego. Projekty myślicieli okresu autonomii galicyjskiej, w: W. Szulakiewicz (red.), Przetomy edukacyjne. Dziedzictwo polskiej teorii i praktyki, Toruń 2011, s. $111-126$.

${ }^{24}$ H. Radlińska, Z zagadnień pedagogiki społecznej, dz. cyt.
${ }^{25}$ Tamże. 
„materiałem” do wychowawczego urabiania. Jest możliwością, potencjałem, kapitałem społecznym, wreszcie - przyszłością narodu; ważną częścią sił społecznych, które będą rozstrzygać o przyszłości kraju. Indywidualny rozwój dziecka jest zatem ściśle związany z rozwojem ojczyzny. Podobnie w tamtym czasie o dziecku wypowiadają się, walcząc o „prawa dziecka do szacunku”, wspomniany Janusz Korczak oraz Stefania Sempołowska. Dzieje się to w klimacie postulatów Nowego Wychowania, które w początkach XX wieku z wolna docierają do polskiej pedagogiki.

Natomiast wykorzystana przez Radlińską kategoria „rozwoju” przenosi myślenie o wychowaniu i szkole na grunt pragmatyczny i realistyczny: rozwój ma być instrumentem realizacji szczytnych haseł upodmiotowienia dziecka. W tym przypadku autorkę interesuje nie rozwój psychiczny młodego pokolenia, na czym koncentruje się ówczesna psychologiczna pedagogika, ale „możliwości rozwoju”. Ma to swoje dalekie konsekwencje. Krok ten otwiera pole teorii i praktyki pedagogiki społecznej, która nie tylko formułuje hasła przebudowy i budowy nowego wychowania, ale zajmuje się także krytyczną analizą warunków rozwoju młodego pokolenia. Radlińska $\mathrm{z}$ naciskiem podkreśla, iż realizacja powszechnego nauczania i obowiązku szkolnego zależy m.in. od zapewnienia każdemu uczniowi odpowiedniego odżywiania i ubrania, ochrony dziecka przed ciężką pracą fizyczną, dostępu dzieci z biednych rodzin do wyższych szczebli kształcenia, niezwalniania z obowiązku szkolnego dzieci biedoty, gdyż $\mathrm{w}$ innym przypadku - jak podkreśla - będą to „nowe ofiary molocha nędzy i ciemnoty"26. Zapewnienie warunków bytowo-socjalnych najbiedniejszym warstwom społeczeństwa nie jest aktem dobrodziejstwa, lecz obowiązkiem państwa i społeczeństwa, świadectwem rozwoju społecznego. Nie będzie można tego osiągnąć bez szerszych zmian w statucie społecznoekonomicznym. Radlińska nie ma tu żadnych wątpliwości: „Ośmiogodzinny dzień roboczy - pisze - spokojna o jutro myśl proletariusza i jasna lampa w chacie chłopskiej są tak samo koniecznymi warunkami wychowania narodowego, jak nędza, troska i ciemnota, przytłaczające masy ludowe przeszkodami, o które się rozbija praca oświatowa" ${ }^{27}$.

Szerokie, nowatorskie i prospektywne spojrzenie na wychowanie i szkołę znajduje rozwinięcie podczas II Polskiego Kongresu Pedagogicznego we Lwowie (1-2.11.1909), kiedy to Radlińska, podejmując polemikę z tezami Zygmunta Balickiego (referat odczytuje W. Lutosławski), wygłasza referat Podstawy wychowania narodowego. Twierdzi wówczas już po raz drugi, iż wychowanie narodowe nie polega na „ciągłym oglądaniu się na groby”, ale na „czerpaniu materiału z dnia dzisiejszego i opierając się na badaniach

\footnotetext{
${ }^{26}$ Tamże.

${ }^{27}$ H. Orsza [H. Radlińska], Praca oświatowa wobec zadań wychowania narodowego, w: Praca oświatowa, jej zadania, metody, organizacja..., dz. cyt, s. 148.
} 
psychologicznych dziecka polskiego przystosowuje się do potrzeb społeczeństwa, stwarza własną metodę i ideologię". I dodaje, formułując kolejną zasadniczą tezę pedagogiki społecznej: „Wychowanie młodzieży jest jedną z czynności życia narodowego i w ścisłym pozostaje związku z jego całoksztaltem" ${ }^{28}$. Z przytoczoną myślą łączy się kolejne fundamentalne twierdzenie pedagogiki społecznej: „Szkolnictwo nie jest (...) jedyną formą wychowania narodowego. Obok niego nieraz silniej działają inne wpływy wychowawcze - przykład otoczenia i atmosfera ogólna; dopełniają je, nieraz zastępują instytucje oświaty pozaszkolnej, biblioteki, muzea, uniwersytety ludowe. Dla nas w chwili obecnej są one tym ważniejsze, że swobodniej niż szkoły mogą służyć istotnym potrzebom narodu"29. Radlińska uogólnia przytoczone myśli w bardzo ważnym tekście Praca oświatowa wobec zadań wychowania narodowego, w którym pisze m.in.: „(...) Pedagogika społeczna wykazuje coraz dobitniej jak rozliczne związki zachodzą między jednostką i społeczeństwem, jak każdy - świadomie lub nieświadomie jest duszą w swoją ojczyznę wcielony"30.

Zarysowana koncepcja szkoły uspołecznionej jest - jak pisze Radlińska - szkołą, która „istnieje w ideale" ${ }^{31}$. Obywatelskie podłoże i demokratyczna treść tej koncepcji sprawia, że mogła być ona w tamtym czasie i tamtym miejscu czymś na kształt - wręcz - rewolucji egalitarnościowej oraz rewolucji ekspresywistycznej. Jej założenia podkreślają równość wszystkich ludzi i podmiotowość każdej jednostki z osobna. Takie odczytywanie funkcji wychowania odwraca lub uzupełnia znaną maksymę Jana Zamojskiego. Radlińska twierdzi i podkreśla, że wychowanie jest takie, jakie są Rzeczypospolite (a nie odwrotnie); że podmiotem wychowania jest cały naród; że wychowanie narodowe jest możliwe tylko $\mathrm{z}$ równoczesną budową niezależnego życia narodowego oraz ogólną demokratyzacją stosunków społecznych; że - wreszcie - głównym celem tego wychowania jest budzenie oraz wyzwalanie sił jednostki i narodu. Tymczasem, jak dodaje Radlińska w innym miejscu: „Nie potrafimy stwarzać programów wychowawczych w związku z potrzebami narodu, stawiać i bronić własnych żądań nawet wówczas, gdy mamy możność działania”. I konkluduje dość brutalnie:

${ }^{28}$ H. Orsza [H. Radlińska], Podstawy wychowania narodowego, w: J. Kornecki (oprac.), Księga pamiatkowa II Polskiego Kongresu Pedagogicznego, dz. cyt.; przedr. w: W. Theiss, Radlińska, dz. cyt. Zob. także: Wł.W., Kongres pedagogiczny we Lwowie, „Krytyka” 1909, t. 3; A. Sujkowski, A. Szycówna, Wrażenia z Polskiego Kongresu Pedagogicznego we Lwowie, „Nowe Tory” 1909. z. IX.

${ }^{29}$ H. Orsza [H. Radlińska], Podstawy wychowania narodowego, dz. cyt.

${ }^{30}$ Tejże, Praca oświatowa wobec zadań wychowania narodowego..., dz. cyt., s. 146.

${ }^{31}$ Tejże, Ze spraw wychowawczych, „Krytyka” 1909, t. 1, z. 1. 
„W długiej niewoli «nawykły jarzmo dźwigać łby»”32 oraz: „Jesteśmy krajem nędzarzy, bo nim być chcemy. Boimy się spojrzeć na swój dorobek, w całej pełni go oświetlić i w całej jaskrawości go zestawić z potrzebami i warunkami życia narodowego. $\mathrm{W}$ dwu zaborach wpływa na to trwoga odsłonięcia swych sił żywotnych: «broni swego rycerza przed wrogiem», w trzecim występuje brak wszelkiej inicjatywy i szacunek przede wszystkim autorytetom, brak dumnego poczucia swych praw i siły i obok rozpolitykowania obojętność dla „«roboty» społecznej ${ }^{33}$.

Dystans, który dzieli ideał szkoły społecznej od ówczesnych realiów sprawia, że zadaniem wszystkich demokratycznych sił społecznych i oświatowych jest walka o nową obywatelską szkołę. Wykorzystywana w tym celu praca oświatowa ma i powinna mieć charakter „bojowy”; nie jest to działalność apolityczna. Jest „bojowa” dlatego, że ma za sobą wiele martyrologicznych kart, zapisanych w walce z przemocą polityczną zaborców. Obecnie zaś jest „bojowa”, gdyż musi walczyć o materialne i moralne warunki bytu, występować przeciwko „ciemnocie, ospałości i bierności”. Funkcją tej walki jest budowanie tożsamości narodowej, samowiedzy politycznej, a jej formą - praca u podstaw z ludem ${ }^{34}$.

\section{O szkołę powszechną w niepodległym kraju}

Przełom lipca i sierpnia 1914 roku jest datą szczególną w dziejach kraju, także dla losów obozu niepodległościowego. Paramilitarna organizacja ochotnicza (Strzelec) pod dowództwem Józefa Piłsudskiego wkracza na teren zaboru rosyjskiego. Polacy przystępują do walki o niepodległość kraju. W wyniku rozwoju akcji wojskowej drużyny strzeleckie zostają przeformowane w Legiony Polskie. Współczesny historyk napisze: „W pamięci zbiorowej Legiony utrwaliły (...) swe miejsce przede wszystkim jako symbol postawy niepokornej, dumnej wolności, odwagi, honoru, zawadiackiej fantazji - były wszak pierwszym realnym spełnieniem śnionego od powstania styczniowego polskiego snu o szpadzie - snu, który w dodatku znalazł w 1918 roku swój

32 Tejże, W sprawie polskiego dorobku wychowawczego, „Muzeum” 1910, t. 1 [Referat na posiedzenie Komisji Polskiego Muzeum Szkolnego, 4.11.1909]; skrót w: „Przewodnik Pracy Oświatowej” 1910, $\mathrm{nr} 1$.

${ }^{33}$ H.O. [H. Radlińska], Ze spraw wychowania i oświaty (I), „Krytyka” 1909, t.3.

${ }^{34}$ H.O. [H. Radlińska], Ze spraw oświatowych (I, II), „Krytyka” 1909, t. 1, z. 4, z. 6; H. Orsza [H. Radlińska], Ze spraw wychowawczych, „Krytyka” 1909, t. 1; H.O. [H. Radlińska], Ze spraw oświatowych, „Krytyka” 1910, t. 1. Wyniki obszernych badań nad genezą i rozwojem pracy oświatowej Radlińska przedstawia w studium: Początki pracy oświatowej $w$ Polsce, w: Praca oświatowa, jej zadania, metody, organizacja..., dz. cyt., s. 1-115; przedr. w: tejże, Z dziejów pracy spotecznej i oświatowej..., dz. cyt., s. 37-107. 
szczęśliwy finał”35. Czyn legionowy w sposób zasadniczy wpływa na koncepcje społeczno-pedagogiczne H. Radlińskiej. Nowe zadania, które wtedy podejmuje, to - w wymiarze ogólnym - praca na rzecz konsolidowania społeczeństwa polskiego w dążeniu do niepodległości kraju, a w wymiarze szczegółowym - propagowanie czynu zbrojnego, kształtowanie postaw poparcia i ofiarności społecznej dla wysiłku Legionów, a także - dalsze projektowanie modelu demokratycznej szkoły dla niepodległej ojczyzny.

Skupiając się $\mathrm{w}$ punkcie wyjścia na charakterystyce sytuacji gospodarczo-politycznej oraz nastrojów społecznych, jakie występują w latach 1914-1918 na ziemiach polskich, Radlińska stawia pytanie o stan gotowości poparcia walki o niepodległość. Pilnie śledzi wszystko to, co przeszkadza zrywowi bojowemu. Lista spostrzeżeń, a tym samym zarzutów, jest długa i zróżnicowana. Obejmuje tak zagadnienia polityczne (autokratyczna władza zaborców, współpraca Polaków z zaborcami, zesłania na Sybir, antypolskie restrykcyjne prawo pruskie), sprawy gospodarcze (rabunkowa gospodarka obcego kapitału, emigracja zarobkowa), jak i problemy kulturowo-społeczne, $\mathrm{w}$ tym zagadnienie systemu wartości i postaw (dzielnicowe rozbicie społeczeństwa, tradycja stania na uboczu życia, aktywność w obrębie filantropii, bierność, strach, brak społecznego współdziałania, brak zrozumienia dla działalności oświatowej). $Z$ drugiej strony zauważa także i podkreśla obecność takich „źródeł mocy” jak: ruch walki i oporu (tradycje niepodległościowe, struktury paramilitarne, tajna oświata, podziemna prasa), pomoc i współpraca społeczno-polityczna (Galicja jako „schronisko polskiej myśli i bojowników wszystkich walk o wolność”), nowe formy pracy kulturalno-społecznej (muzea, pozaszkolne instytucje popularyzacji wiedzy, ruch oświaty robotniczej i ludowej $)^{36}$.

Naszkicowany obraz polityczno-społecznych realiów kraju pod zaborami, choć wybiórczy i mozaikowy, budowany $z$ pozycji osoby zaangażowanej $\mathrm{w}$ bieg historii, jest dla Radlińskiej fundamentalnie ważny zarówno ze względów politycznych, jak i szeroko rozumianych względów oświatowo-wychowawczych. Oto oparciem prac szkolno-oświatowych mają być „oddolne” realia, rzeczywiste problemy codziennego życia, a nie zewnętrzne, „odgórnie” narzucone dogmaty, idee i hasła. Stąd, z miejsca i czasu, w którym żyją Polacy, z ich doświadczeń i przeżyć, z pragnień i ideałów,

${ }^{35}$ A. Nowak, Legiony polskie w I wojnie światowej, w: Z. Najder i in. (red.), Węzhy pamięci niepodległej Polski, Kraków-Warszawa 2014, s. 400.

${ }^{36}$ Warszawianin [H. Radlińska], „My a wy”, „Wiadomości Polskie” 1914, nr 3; H. OrszaRadlińska, Galicja i Królestwo, „Wiadomości Polskie” 1916, nr 86; Anonim [H. Radlińska], Zadania pracy kulturalnej, „Kultura Polski” 1917, z. I; h.o. [H. Radlińska], Program pracy oświatowej, „Kultura Polski” 1917, z. VI; Anonim [H. Radlińska], Zadania pracy kulturalnej, „Kultura Polski” 1917, z. I; Anonim [H. Radlińska], Rola inteligencji, „Kultura Polski” 1918, z. XXII-XXIII; H. Orsza [H. Radlińska], Program pracy oświatowej, „Kultura Polski” 1918, z. XXXVIII. 
które kultywują, a także z ich niezadowolenia i krzywdy pochodzą bieżące zadania: walka zbrojna, praca nad przemianami społecznymi, działalność oświatowo-wychowawcza. Scala te zadania myśl nadrzędna: „zniesienie kopców granicznych" dzielących kraj. Perspektywa ta obejmuje wszystkich, tzn. nie pomija ani nie eliminuje nikogo i bez wyjątku jest skierowana do wszystkich mieszkańców ziem polskich.

Nowa sytuacja historyczna z całą mocą stawia na planie pierwszym w obrębie wychowania narodowego kategorię „czynu”, także „czynu zbrojnego”, „walki”, „bojownika”, „żołnierza polskiego”. Radlińska wielokrotnie pisze na ten temat na łamach „Wiadomości Polskich”, nawołując do bezwarunkowego i ofiarnego udziału w walce zbrojnej o wolnośćc ${ }^{37}$. W tym celu sięga po ważną symboliczną, wzorotwórczą rolę, jaką pełni ów idealny „polski żołnierz”. Mówi, że jest to postać, która wyrasta z narodowych dążeń niepodległościowych, tak różnych od serwilistycznych nastawień, powstałych m.in. z biernego podporzadkowania się tradycji. „Żołnierz polski nie snuje marzeń" - wyjaśnia w 1915 roku Radlińska, uderzając w nader wysokie tony - „nie tłumaczy swego postępowania, nie rozwodzi się nad niebezpieczeństwami. Walczy. Wierzy w siły swoje i narodu, którego jest cząstką do czynu najbardziej przygotowaną. Jedyną próbą życia narodowego jest dziś próba siły. Obudziła się uśpiona siła Polski w tym czynie zbrojnym. Przyszłość narodu od jej mocy zależy" ${ }^{38}$. W innym miejscu dodaje stanowczo: „W świecie politycznym jest miejsce tylko dla sily, dla życia. Glos skargi nie budzi echa (...)"39. Pisząc o walce, Radlińska wskazuje na jeszcze jedno niezwykle ważne pole koniecznego działania: „Bój o Polskę trzeba stoczyć nie tylko z wrogiem. Trzeba go podjąć także z jadem niewoli, który się wżarł w dusze i zatruł typ Polaka, wykrzywiając go w "patriotę» swojego zaborcy"

Każdy środek prowadzący do „czynu” jest ważny - nawet legenda. Radlińska uważa, że „wydarzenia legionowe” stały się źródłem legend opisujących zmarłych bohaterów, ich śmiałe, pobudzające wyobraźnię czyny na polach bitew. Zawarta w legendzie „idealna wartość ofiar” może i powinna zagrzewać do wytrwania w walce i do bohaterstwa. Jest to „zadatek odporności i mocy nowych bojowników”. Uwagi te zamyka oczywista dla autorki myśl: taka krzepiąca legenda snuje się wokół Piłsudskiego i pierwszych Strzelców ${ }^{41}$.

${ }^{37}$ O. [H. Radlińska], Wartość ofiar, „Wiadomości Polskie” 1915, nr 51; Anonim [H. Radlińska], Ofiarność spoleczeństwa polskiego na Legiony, „Wiadomości Polskie” 1914, nr 1; O. [H. Radlińska], Wieści ze Lwowa, „Wiadomości Polskie” 1914, nr 6; O. [H. Radlińska], Polski Skarb Wojskowy, „Wiadomości Polskie” 1915, nr 40-41; J. Strumiński [H. Radlińska], Pomoc społeczeństwa dla armii, „Kultura Polski” 1917, z. II.

${ }^{38}$ O. [H. Radlińska], O polskiej prawdzie. „Wiadomości Polskie” 1915, nr 30.

${ }^{39}$ Tejże, Wartość ofiar, „Wiadomości Polskie” 1915, nr 51.

${ }^{40}$ Warszawianin [H. Radlińska], „My a wy”, „Wiadomości Polskie” 1914, nr 3.

${ }^{41}$ H.O. [H. Radlińska], Legenda, „Wiadomości Polskie” 1915, nr 52. 
Poza sferę zaangażowanej, agitacyjnej i propagandowej publicystyki społecznej prowadzonej w duchu legionowym wykraczają prace prowadzone od 1914 roku przez Ksawerego Praussa w ramach Centralnego Biura Szkolnego (CBS), agendy Naczelnego Komitetu Narodowego (NKN) sprawującego formalny patronat nad Legionami. Zadaniem Biura jest przygotowywanie nauczycieli do nowych zadań w niepodległym kraju, dostarczanie szkołom książek i pomocy naukowych, a także budowanie modelu przyszłej szkoły polskiej. W 1917 roku Prauss wydaje projekt pt. W sprawie realizacji powszechnego nauczania $w$ Królestwie Polskim ${ }^{42}$. Wypowiadając się w duchu działań NKN i ściśle współpracując z Praussem, Radlińska intensywnie rozwija wcześniejsze założenia szkoły społecznej i demokratycznej. Co niemal oczywiste, nadal jest to szkoła jednolita i uspołeczniona, i nadal - jak pisze Radlińska - „kształtuje [ona] życie «nowych ojczyzny następców»”. Jednakże widoczne w tym obrazie nowe akcenty - idee, zadania i rozwiązania - mają jedno na uwadze: scalenie „akcji szkolnej” i powolne jej wprowadzanie w ramy władzy państwowej i w system szkolny niepodległego już kraju.

W 1914/15 roku Radlińska publikuje ważny tekst Zagadnienie narodowego wychowania, w którym po raz kolejny, ale tym razem w nowym kontekście historycznym, precyzuje warunki, które muszą być spełnione w pracach nad szkołą dla niepodległego kraju. Wymienia m.in.: szerokie uświadamianie ideałów wychowawczych, przygotowanie kadr szkolnych, tworzenie programów nauczania opartych na własnych tradycjach i najlepszych wzorach. Mowa też o wychowaniu, które ma budować jedność Polski, przygotowywać „człowieka silnego, umiejącego pracować”. Szkoła taka powinna jednocześnie odsłaniać „niezużytkowane bogactwa” kraju, ukazywać jego bieżącą chwilę, występujące trudności i zadania. Aby nie było wątpliwości, Radlińska podkreśla, że jest to szkoła jednolita, dostępna i obowiązkowa dla wszystkich bez względu na wyznanie, pochodzenie, majątek ${ }^{43}$. Jakiś czas później, już w 1918 roku, Radlińska zauważy, iż taka szkoła powszechna zapewni każdemu podstawy rozwoju, da pewien, uznany za powszechny, „zasób wiedzy i ogłady”, przygotuje także do dalszej nauki ${ }^{44}$.

Ważną rolę w procesie wychowania i budzenia świadomości związków młodego pokolenia z narodem pełni nauczanie historii. Radlińska wypowiada się na ten temat już wcześniej ${ }^{45}$, ale obecnie postuluje nowatorskie łączenie celów historii z treściami przyrodniczymi, geograficznymi, etnograficznymi

\footnotetext{
${ }^{42}$ H. Radlińska, Z dziejów pracy spotecznej i oświatowej..., dz. cyt., s. 321-328; H. Grotowska, Ksawery Prauss (1874-1925), „Przegląd Historyczno-Oświatowy” 1947, nr 2.

${ }^{43}$ H. Orsza-Radlińska, Zagadnienie narodowego wychowania, „Wiadomości Polskie” 1914/15, nr $57-58$.

${ }^{44}$ H. Orsza [H. Radlińska], Pilna sprawa szkolna, „Kultura Polski” 1918, z. XXXIX.

${ }^{45}$ Tejże, $W$ sprawie popularyzacji historii, „Nowe Tory” 1911, z. 1.
} 
w przedmiocie o nazwie „nauka rzeczy ojczystych”, który ma wprowadzać uczniów w ogół stosunków społeczno-kulturowych kraju. Według autorki jest to urzeczywistnianie idei „elementarnej nauki narodowej”, głoszonych wcześniej przez Ewarysta Estkowskiego ${ }^{46}$.

Innym jeszcze postulatem o pilnym charakterze, jaki Radlińska wówczas zgłasza, jest utworzenie szkoły dla profesorów seminariów nauczycielskich. Może ona przejściowo przybrać formę kursów dla absolwentów szkół średnich, ludzi o rozległej wiedzy, ale bez pedagogicznego wykształcenia. Pierwszeństwo $\mathrm{w}$ naborze na taki kurs oraz $\mathrm{w}$ otrzymaniu stypendium posiadają osoby, które legitymują się stażem pracy w szkołach powszechnych. Program opisywanego kursu zawiera treści z zakresu języka polskiego, wiedzę o Polsce współczesnej, historię myśli i praktyki pedagogicznej, psychologię, higienę szkolną oraz metodykę pozaszkolnej pracy oświatowej. Nauka obejmuje także zwiedzanie najważniejszych ośrodków życia narodowego. Radlińska nie wątpi, że nauczyciel wyposażony w wymienione treści będzie, świadom swoich zadań, dobrze kształcić nowe pokolenie nauczycieli dla odrodzonej Polski ${ }^{47}$.

Na zarysowanym tle wyodrębniają się uwagi Radlińskiej kierowane do przyszłych władz szkolnych w wolnym kraju. Spuścizna szkolna po zaborcach sprawi, że trudne będzie tworzenie systemu edukacji narodowej, kształtowanie szacunku i posłuchu wobec nowej władzy, a także zapobieganie działaniom rozbieżnym i chaosowi. Ostrzega przyszłą władzę przed monopolizowaniem nauczania i wychowania, zachęca do wykorzystywania sprawdzonych doświadczeń szkolno-oświatowych i otwierania się na pomoc ze strony inicjatywy prywatnej. Natomiast niezbywalnym zadaniem nowych władz szkolnych jest stanie „na straży ideałów narodowych i pedagogicznych”. Ta nowa powszechna szkoła w niepodległym kraju musi, w imię społecznych powinności i zgodnie z zasadą dialogu społecznego, szukać sprzymierzeńców i wchodzić $\mathrm{w}$ mariaże $\mathrm{z}$ jak najszerszymi masami obywatelskimi, kręgami rodziców, pozaszkolnymi instytucjami kulturalnymi, wychowawczymi i opiekuńczymi ${ }^{48}$. Jak latwo dostrzec, jest to rozwinięta wcześniejsza teza o szkole uspołecznionej, myśl, która w prostej linii prowadzi do dzisiejszych koncepcji budowania partnerstwa szkoły, rodziny i gminy.

W 1918 roku ogół wysiłków narodowych skupionych na walce o niepodległość kraju sprawia, jak pisze Radlińska nie bez emocji, że „to, co było marzeniem i frazesem: Polska ludowa - rękami ludu całego budowana,

\footnotetext{
${ }^{46}$ Tejże, $Z$ metodyki nauczania historii $w$ szkole. Cele nauczania historii, „Ruch Pedagogiczny” 1913, nr 8; tejże: O nauczaniu historii Polski $w$ szkole początkowej. Szkic programu, Dąbrowa Górnicza 1915.

${ }^{47}$ Tejże, Najpotrzebniejsza szkoła, „Kultura Polski” 1918, z. II.

${ }^{48}$ H. Orsza-Radlińska, Wobec polskiego ministerstwa oświaty, „Kultura Polski” 1917, z. III.
} 
stać się ma za dni naszych ciałem (...). Ogół obywateli nigdy jeszcze nie był powołany do tylu obowiązków, co obecnie. W pośpiechu dokonywać się winno uświadomienie najszersze, na czym one polegają: zapoznawanie się z zagadnieniami życia narodowego, z tradycjami pracy i dotychczasowym dorobkiem w każdej dziedzinie" ${ }^{49}$.

Powstaje ważne pytanie: jak wtedy Radlińska rozumie tę wyobrażoną „Polskę ludową” i jej rolę $\mathrm{w}$ wychowaniu? Odpowiedź na te pytania przedstawia w 1919 roku w artykule o znamiennym tytule $O$ nowe życie. Pisze w nim m.in.: „Po uzyskaniu podstawowych praw obywatelskich, po pierwszej próbie brania w swoje ręce rządów w Polsce - lud musi sięgnąć po prawo do kultury, wziąć je sobie i tak życie narodu urządzić, by wszyscy w miarę zdolności mogli korzystać z wiedzy, z piękna i wysnuwać z siebie dla radości powszechnej przędy myśli i sztuki”. Po tym ogólnym, wstępnym wyjaśnieniu Radlińska przedstawia tezy na temat „Polski ludowej”, które składają się na swoisty przewodnik po przyszłym kraju, a zarazem - listę wyzwań, które stoją przed narodem. Oto niektóre z tych wskazań:

- „(...) Chcemy obalić przesąd, że rolnik musi być ciemny, robotnik - ma szukać rozrywki w szynku, a „inteligent” czy „pan” mieć prawo do wszystkich zdobyczy kultury (choćby ich nie był w stanie odczuć);

- Chcemy, by wychowanie młodzieży wydobywało z dzieci całego narodu zdolności i kształciło jak najpełniej człowieka, który sam potrafi postanowić, jaką drogą pójdzie w życie, by najjaśniej rozpalić swoją iskrę bożą (...);

- Po 7-letniej szkole powszechnej powinny stać dla młodzieży otworem różne szkoły ogólnokształcące i zawodowe, rolnicze, przemysłowe itd.;

- Nie można ludzi rozbudzonych przez szkołę zostawić potem na pastwę śpiączki umysłowej. Nie można dziś, gdy wszyscy ludzie dorośli budują dla następnych pokoleń nowe życie, poprzestać na uczeniu dzieci;

- Państwo ludowe musi udostępnić każdemu obywatelowi: książki, obrazy, wiedzę, muzykę. Trzeba całą Polskę pokryć siecią bibliotek powszechnych, zakładać piękne domy ludowe, urządzać wystawy, odczyty i koncerty (...);

- Bądźmy siewcami nowego życia" ${ }^{\circ}$.

Zasygnalizowane, radykalne i lewicowe o proweniencji socjalistycznoludowej idee społeczno-oświatowe wraz z Radlińską podzielali (lub byli do nich zbliżeni) tacy działacze, jak na przykład Jadwiga Dziubińska, Iza Moszczeńska, Zygmunt Nowicki, Władysław Radwan, Stefania Sempołowska, Władysława Weychert-Szymanowska. Po przeciwnej stronie barykady stały stronnictwa prawicy politycznej, środowiska właścicieli przemysłowych,

\footnotetext{
${ }^{49}$ Anonim [H. Radlińska], Zadania pracy kulturalnej, „Kultura Polski” 1917, z. 1.

${ }^{50}$ H. Orsza [H. Radlińska], O nowe życie, „Wyzwolenie” 1919, nr 8; przedr. w: H. Radlińska, Oświata i kultura wsi polskiej. Wybór pism, wstęp H. Brodowska, Warszawa 1979, s. 168-171.
} 
konserwatywne ziemiaństwo, hierarchia kościelna. Postępowe zasady polityki szkolnej i oświatowej weszły w skład programów przedstawianych i aprobowanych podczas Sejmu Nauczycielskiego w 1919 roku. Projekty te, w których niezmiennie obecny był duch obywatelski, emancypacyjne ideały oświeceniowe oraz poczucie odpowiedzialności za państwo, znalazły się $\mathrm{w}$ deklaracji pierwszego $\mathrm{w}$ niepodległym kraju rządu Jędrzeja Moraczewskiego, a także $\mathrm{w}$ programach Ksawerego Praussa, pierwszego ministra Wyznań Religijnych i Oświecenia Publicznego w wolnej Polsce ${ }^{51}$.

Naszkicowany skrótowy obraz polskiej szkoły narodowej, obecny w publicystyce społecznej Radlińskiej okresu 1906-1918 jest z wielu względów ważny, a wiedza o nim - potrzebna (choćby ze względów dokumentacyjnych). Twórczość ta, dotąd raczej pomijana $\mathrm{w}$ opracowaniach poświęconych Radlińskiej, przybliża obraz - sięgając do zwrotu Bogdana Nawroczyńskiego - „pedagogiki wzmożenia duchowego”. Jest to ważne ogniwo rozwoju polskiej myśli i praktyki pedagogicznej, faza, w której wysiłek szkolno-wychowawczy, w przeciwieństwie do pedagogiki pozytywistycznej czy obecnej także wtedy pedagogiki formalnej, jak również powstającej wówczas pedagogiki empirycznej o nastawieniu psychologicznym, angażuje się w pracę na rzecz kraju, narodu i społeczeństwa. Nawroczyński stwierdzi, że to pedagogika, która poszła w „służbę czynu narodowego" ${ }^{2}$.

Po latach Radlińska swoją działalność polityczno-społeczną nazwie „stawianiem drogowskazów pracy społecznej towarzyszącej walce”. I stwierdzi: „Był to jedyny okres w moim życiu zajmowania się publicystyką, której na ogół nie lubię, nawet unikam jako sprzecznej z metodą badań naukowych. Warunki ówczesne wymagały jednak posługiwania się środkami publicystyki: oświetlania tego, co w danej chwili najaktualniejsze, przemawia do woli" ${ }^{53}$. Dzisiaj trudno podzielać tę przesadnie skromną, zawężoną, krytyczną samoocenę.

Radlińska, łącząc oświatę i wychowanie z polityką, a zadania polityczne z przesłankami moralnymi, uczy krytycznego patrzenia na siebie i świat; uczy dostrzegania związków pomiędzy różnymi wymiarami życia, a także pomiędzy „dziś”, „wczoraj” i ,jutro”. Pomaga w walce z przemocą, niewiedzą, ciemnotą, nacjonalizmem. Nie jest to pedagogika (praca oświatowa) tanich hasel, krytycznych spekulacji, abstrakcyjnych koncepcji. Jest to pedagogika krytycznego czynu. W projektowanych i prowadzonych działaniach zawsze na planie pierwszym sytuuje człowieka, z którym dialoguje, współpracuje, współtworzy nowe zręby środowiska życia człowieka. Rodzi się wśród ludzi, we

${ }^{51}$ Zob. H. Radlińska, Z dziejów pracy społecznej i oświatowej..., dz. cyt., s. 373-375; R Wroczyński, Marian Falski i reformy szkolne w Rzeczypospolitej, Warszawa 1988, s. 89-106.

52 B. Nawroczyński, Polska myśl pedagogiczna, Lwów-Warszawa 1938, s. 105.

${ }^{53}$ H. Radlińska, $Z$ dziejów pracy społecznej i oświatowej..., dz. cyt., s. 368 
współpracy z ludźmi i ludziom ma służyć. Z tego tworzywa, z postaw demokratycznych, krytycznych, realistycznych i twórczych wyrasta, budowany przez Helenę Radlińską, nowy wtedy w polskich warunkach kierunek pedagogiki: pedagogika społeczna.

Streszczenie: Helena Radlińska (1879-1954), historyk i pedagog, w latach 1907-1918 była znaną działaczką tzw. obozu niepodległościowego, ugrupowania, które na czele z Józefem Piłsudskim walczyło o niepodległość kraju. W klimacie ówczesnych wydarzeń historycznych, politycznych sporów, a także ścierających się wizji niepodległego kraju, Radlińska tworzyła i propagowała koncepcję polskiej szkoły. Był to projekt śmiały, bezkompromisowy i przyszłościowy. Odwoływał się do tradycji Komisji Edukacji Narodowej oraz doświadczeń szkół demokratycznych m.in. w Stanach Zjednoczonych i Szwajcarii. Przede wszystkim jednak uwzględniał edukacyjne potrzeby społeczeństwa polskiego, tak czasu zaborów, jak i przyszłego niepodległego kraju. Projekt ewoluował od modelu „szkoły walczącej” z rozwiązaniami edukacyjnymi zaborców oraz z programami wychowawczymi krajowych środowisk ugodowych, poprzez „szkołę społeczną”, która miała gwarantować naukę wszystkim dzieciom, bez względu na różnice społeczne, ekonomiczne, wyznaniowe, po model „szkoły wolnej Polski”, szkoły skoncentrowanej na wychowaniu patriotów i zaangażowanych obywateli oraz realizującej pogłębiony program wiedzy o Polsce. Budowany przez Radlińską, przełomowy i przyszłościowy, oparty na niezbywalnych wartościach demokracji, projekt polskiej szkoły zajmuje ważne miejsce w dziejach polskiej myśli oświatowo-wychowawczej pierwszych dwóch dekad XX wieku

Słowa kluczowe: Helena Radlińska, Kraków, obóz niepodległościowy, demokratyczne tradycje oświatowe, czyn narodowy, walka o kulturę, oświatowiecbojownik, szkoła uspołeczniona, praca kulturalno-społeczna, pedagogika społeczna 